\title{
LXI. Saturation of salt-solutions
}

\author{
W.W.J. Nicol M.A. B.Sc. F.R.S.E.
}

To cite this article: W.W.J. Nicol M.A. B.Sc. F.R.S.E. (1884) LXI. Saturation of salt-solutions, Philosophical Magazine Series 5, 17:109, 537-550, DOI: 10.1080/14786448408627554

To link to this article: http://dx.doi.org/10.1080/14786448408627554

$$
\text { 曲 Published online: } 29 \text { Apr } 2009 .
$$

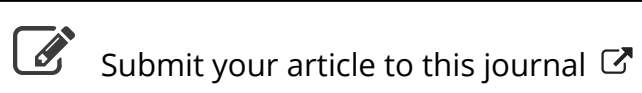

\footnotetext{
LII Article views: 4
}

Q View related articles $\asymp$ 


\section{$\left[\begin{array}{ll}537 & ]\end{array}\right.$}

LXI. Saturation of Salt-Solutions. By W. W. J. Nico L, M.A., B.Sc., F.R.S.E., \&c., Lecturer on Chemistry, Mason College, Birmingham*.

A CCORDING to the theory of solution brought forward $A$ in my paper on the Nature of Solutiont, saturation of a solution of a salt results when the sum of the attractions of the salt-molecules present in the solution for any individual salt-molecule is equal to the sum of the attractions of the water-molecules for that particular salt-molecule-the attraction of the water-molecules for one another being disregarded, as a probably constant quantity. At that time I endeavoured to prove that the attraction of the dissimilar molecules of water and salt is one cause of the contraction attending the solution of a salt, while the attraction of the similar molecules of the salt has an opposite effect, and tends to produce an increase in the volume.

I wished at the time of publication of the above to show a connexion between the molecular volume of a salt in the solid state and its solubility. That such a connexion does exist, my early experiments soon convinced me. But as yet I am in a position only to indicate the nature of this relation; sufficient evidence is still wanting to give my conclusions a quantitative value.

The results $\ddagger$ obtained by comparisons of the molecular volumes of dilute solutions of various salts, show that in such solutions the intermolecular spaces are practically coextensive whatever may be the salt, while this is clearly not the case in the solid state, except with isotomous salts. In solution the molecules of salt are so far apart that they are out of the sphere of one another's attraction; in the solid state, on the other hand, they are packed more or less closely together, according to the temperature $\S$ of crystallization and the attraction they have for one another. If, now, the above theory of saturation be the correct one, it is evident that, since loose packing of the molecules-that is, large molecular volume in the solid state-is due to weak attraction between the molecules of the salt, such a salt should be more easily dissolved than one which differs from it only in the attraction between its molecules being so great as to cause a smaller molecular volume. I hope to be able to show that this is the case.

As already shown by Gerlach and others, the rate of increase

* Communicated by the Author.

$\dagger$ Phil. Mag. 1883, xv. p. 91.

I Phil. Mag. 1883, xv. p. 121, and Ber. d. deut. chem. Ges.

$\$$ Phil. Mag. Feb. 1883, p. 94. 
of the specific gravity of a salt-solution is less than the rate at which it increases in concentration; consequently the molecular volume of each successive molecule of a salt added to a solution is a constantly increasing quantity. Tables I. and II. contain the results of experiments with $\mathrm{NaCl}$.

Table $I$. gives the density $(\delta)$ and the molecular volume (M. V.) of solutions containing $n$ molecules of $\mathrm{NaCl}$ in 100 molecules of water, at $t^{\circ}=20^{\circ}$. The column headed $\Delta$ gives the difference in molecular volume produced by each successive molecule of salt added.

TABLE I.

\begin{tabular}{|c|c|c|c|c|}
\hline \multicolumn{7}{|c|}{$n \mathrm{NaOl}+100 \mathrm{H}_{2} \mathrm{O}}$. \\
\hline$t^{\circ}$. & $n$. & $\delta$. & $\mathrm{M} . \mathrm{V}$. & $\Delta$. \\
\hline 20 & .5 & $1 \cdot 01145$ & $1808 \cdot 54$ & $17 \cdot 08$ \\
$"$ & $1 \cdot 0$ & $1 \cdot 02255$ & $1817 \cdot 52$ & $17 \cdot 96$ \\
$"$ & $2 \cdot 0$ & $1 \cdot 04393$ & $1836 \cdot 29$ & $18 \cdot 77$ \\
$"$ & $3 \cdot 0$ & $1 \cdot 06437$ & $1856 \cdot 03$ & $19 \cdot 74$ \\
$"$ & $4 \cdot 0$ & $1 \cdot 08408$ & $1876 \cdot 23$ & $20 \cdot 20$ \\
$"$ & $5 \cdot 0$ & $1 \cdot 10276$ & $1897 \cdot 42$ & $21 \cdot 19$ \\
$"$ & $6 \cdot 0$ & $1 \cdot 12099$ & $1918 \cdot 84$ & $21 \cdot 42$ \\
$"$ & $7 \cdot 0$ & $1 \cdot 13838$ & $1940 \cdot 92$ & $22 \cdot 08$ \\
$"$ & $8 \cdot 0$ & $1 \cdot 15503$ & $1963 \cdot 59$ & $22 \cdot 67 ?$ \\
$"$ & $9 \cdot 0$ & $1 \cdot 17140$ & $1986 \cdot 09$ & $22 \cdot 50$ \\
$"$ & 10.0 & $1 \cdot 18707$ & $2009 \cdot 15$ & 23.06 \\
$"$ & $10 \cdot 99$ & $1 \cdot 20191$ & $2032 \cdot 76$ & $23 \cdot 61$ \\
\hline
\end{tabular}

The molecular volum $\theta$ therefore increases from 17.08 up to 23.61 for the last .99 molecule added. In Table II. the data are treated differently. The molecular volume of the water is assumed constant $=1800$, and is subtracted from the molecular volume of the solution; the remainder $(\mathrm{M} . \mathrm{V} .-1800)=r$ is what Thomsen has called the "Rest"-it is the volume of the salt in the solution; and $\frac{r}{n}$ is the mean molecular volume of a molecule of the salt in a solution of strength $n:$ this in the case of $\mathrm{NaCl}$ increases from $17 \cdot 08$ to $21 \cdot 16$ in the saturated solution. The molecular volume of the salt in the solid state $\frac{\text { Mol. wt }}{\delta}$ is given by Schröder $=27 \cdot 1$. 
Saturation of Salt-Solutions.

TABLE II.

\begin{tabular}{|c|c|c|c|}
\hline \multicolumn{4}{|c|}{$n \mathrm{NaCl}+100 \mathrm{H}_{2} \mathrm{O}$} \\
\hline$t^{\circ}$. & $n$. & $r$. & $\frac{r}{n}$. \\
\hline 20 & $\cdot 5$ & $8 \cdot 54$ & $17 \cdot 08$ \\
\hline " & $1 \cdot 0$ & $17 \cdot 54$ & $17 \cdot 54$ \\
\hline " & $2 \cdot 0$ & $36 \cdot 29$ & $18 \cdot 14$ \\
\hline$"$ & $3 \cdot 0$ & 56.03 & $18 \cdot 68$ \\
\hline$"$ & $4 \cdot 0$ & $76 \cdot 23$ & $19 \cdot 06$ \\
\hline$"$ & $5 \cdot 0$ & $97 \cdot 42$ & $19 \cdot 48$ \\
\hline$"$ & $6 \cdot 0$ & $118 \cdot 84$ & $19 \cdot 81$ \\
\hline$"$ & $7 \cdot 0$ & $140 \cdot 92$ & $20 \cdot 13$ \\
\hline$"$ & $8 \cdot 0$ & $163 \cdot 59$ & $20 \cdot 45$ \\
\hline$n$ & $9 \cdot 0$ & $186 \cdot 08$ & $20 \cdot 68$ \\
\hline , & $10 \cdot 0$ & $209 \cdot 15$ & $20 \cdot 92$ \\
\hline$"$ & $10 \cdot 9$ & 232776 & $21 \cdot 16$ \\
\hline
\end{tabular}

We have therefore:-

(1) M. V., NaCl solid $\quad=27 \cdot 1$.

(2) Mean M. V., $\mathrm{NaCl}$ saturated solution $=21 \cdot 2$.

(3) M. V., $\mathrm{NaCl} \cdot 5$ molecule solution $=17 \cdot 1$.

Now, $(1-3)=10 \cdot 0$, and $(1-2)=5.9$; and

$$
\frac{(1-2)}{(1-3)}=\frac{5 \cdot 9}{10 \cdot 0}=\cdot 59 \text {. }
$$

But (2) is the mean volume of each molecule in a saturated solution, when the attraction of similar molecules is equal to that of dissimilar molecules; (3), on the other hand, is when only dissimilar molecules act, and (1) only similar ones. Saturation has taken place therefore when the difference between the volume of a molecule of $\mathrm{NaCl}$ in the dissolved state and the volume in the solid state has reached 59 of that between the volume in the solid state and that when the molecules are entirely free from one another's attraction.

Again, in the case of potassium chloride:-

(1) M. V., KCl solid $\quad=37 \cdot 4$.

(2) M. V., KCl in saturated solution $=30.9$.

(3) M. V., $\mathrm{KCl}$ in $\cdot 5$ molecule solution $=27 \cdot 1$.

Here $\frac{(1-2)}{(1-3)}=\frac{6 \cdot 5}{10 \cdot 3}=\cdot 631$. 
Sodium Nitrate.

(1) M. V., $\mathrm{NaNO}_{3}$ solid $\quad=37 \cdot 6$.

(2) M. V., $\mathrm{NaNO}_{3}$ in saturated solution $=34 \cdot 2$.

(3) M. V., $\mathrm{NaNO}_{3}$ in 1 molecule solution $=28 \cdot 2$.

Here $\frac{(1-2)}{(1-3)}=\frac{3 \cdot 4}{9 \cdot 4}=\cdot 361$.

Potassium Nitrate.

(1) M. V., $\mathrm{KNO}_{3}$ solid $=48 \cdot 5$.

(2) M. V., $\mathrm{KNO}_{3}$ in saturated solution $=41 \cdot 4$.

(3) M. V., $\mathrm{KNO}_{3}$ in $\cdot 5$ molecule solution $=38 \cdot 1$.

Here $\frac{(1-2)}{(1-3)}=\frac{7 \cdot 1}{10 \cdot 4}=\cdot 682$.

Now, to compare these results with the solubility, it must be kept in mind that the more nearly the fraction $\frac{(1-2)}{(1-3)}$ approaches to a whole number the greater the attraction of the salt-molecules for one another, and conversely.

TABLE III.

\begin{tabular}{|c|c|c|c|}
\hline Salt. & $\frac{(1-2)}{(1-\overline{3})}$ & Solubility. & $\frac{(1-2)}{(1-3)} \times$ sol. $\times$ Mol. wt. \\
\hline $\mathrm{KNO}_{3} \ldots \ldots$ & 682 & $5 \cdot 63$ & $38 \cdot 7$ \\
\hline $\mathrm{KCl}$ & 631 & $8 \cdot 38$ & $39 \cdot 4$ \\
\hline $\mathrm{NaCl} \ldots \ldots$ & .590 & $10 \cdot 99$ & $38 \cdot 0$ \\
\hline $\mathrm{NaNO}_{3} \ldots$ & $\cdot 361$ & $18 \cdot 45$ & $66 \cdot 6$ \\
\hline
\end{tabular}

We find that the less the solubility the larger the fraction, holds good in all four cases; and I have added to the table, without intending to lay much stress on the result, the product of the fraction by the solubility by the molecular weight. In the three first cases the result is nearly a constant number ; the mean difference is 2 per cent. only, which is little when the number of determinations involved is considered; but $\mathrm{NaNO}_{3}$ is entirely exceptional. I have failed to find any error anywhere, and must leave it at present unexplained. It will be found that this is not the only instance in which $\mathrm{NaNO}_{3}$ behaves differently from the majority of salts. My reason for introducing the molecular weight as a factor in the above calculation is that, other things being equal, the cohesion of the salt is evidently a function of its molecular weight. 
I believe that further investigation will show the general truth of the following conclusions:-

That the more soluble a salt is in any liquid, the more nearly will its mean molecular volume in the saturated solution approach that in the solid state, and that in most cases the product of $\mathrm{F}$ by the solubility by the molecular weight will be found a constant, subject, however, to variations, due most likelylto the influence of the at present unknown factor attraction of salt for water.

That the solubility of a salt is intimately connected with its molecular volume is also shown by the following:-

(1) Diminished molecular volume without change of composition is attended by diminished solubility: thus, in the case of sodium sulphate, the salt crystallized at different temperatures has a different molecular volume ${ }^{*}$.

$\begin{array}{lllr}t^{\circ} & =40^{\circ} & 110^{\circ} & \text { Melted. } \\ \text { M. V. } & =53.35 & 53.31 & 53.96 \\ \text { Solubility } \dagger=48.8 & 42.5 & \left\{\begin{array}{l}230^{\circ} \\ 46.4\end{array}\right.\end{array}$

The solubility here is parts per 100 of water.

Under this head also come the instances given by me (loc. cit.), and also the determinations of the rate at which $\mathrm{CaCO}_{3}$ dissolves in dilute acids in the different forms of calcspar and arragonite, where the former, with a lower specific gravity (i.e. larger molecular volume), was found to dissolve fastest.

(2) Diminished molecular volume with change of composition is attended by diminished solubility.

Sodium sulphate has its maximum of solubility at $32^{\circ} \cdot 8$, the temperature at which the decahydrated molecule is broken up. So with sodium carbonate at $32^{\circ} .5$ (Mulder).

Manganese sulphate has a maximum of solubility at $54^{\circ} \mathrm{C}$., and the solid salt decomposes into a lower hydrate at $54^{\circ}$ (Tilden).

Ferrous sulphate has its maximum at $63^{\circ} \cdot 5$, temperature of decomposition (Tilden). Other cases are given by Mulder $\neq$. But enough has been said to show that here the solubility is connected with the hydration of the salt; but as increased or diminished hydration means increased or diminished molecular volume, the molecular volume is connected with the solubility. I do not intend by the above to imply that in solution the salt is combined with the water of crystallization. I formerly held this, the general view; but experiments, nearly completed,

* Phil. Mag. Feb. 1883, loc. cit.

+ Tilden and Shenstone, Proc. Roy. Soc. xxxv. p. 345.

I MuIder, Bijdragen tot de Geschiedenis van het scheikundig gebonden Water (Rotterdam, 1864).

Phil. Mag. S. 5. No. 109. Suppl. Vol. 17. 
have raised grave doubts, and incline me to the opinion that water of crystallization is indistinguishable, when the salt is dissolved, from water of solution. This, however, does not afiect the above: it is immaterial for the above argument whether the hydrate is ready formed in the solution, or the salt is forced by conditions of temperature \&c. to carry with it that number of water-molecules--the effect on the molecular volume would be the same *.

I come now to the second part of the subject.

Saturation in Solutions of two Salts.

Hitherto we have considered saturation in the solution of a single salt. What laws govern the saturation of a solution with two or more salts? I shall confine my remarks for the present to solutions of only two salts; and this implies that they are salts containing the same metal or the same salt radical.

This is a subject which presents considerable experimental difficulties, and it has been attacked by but a few experimenters, the chief of whom are :-

KopP (1840), Liebig's Annalen, xxxiv. pp. 260-271.

KarSten (1841), Liebig's Annalen, xl. pp. 197-206.

Mulder (1864), loc. cit. pp. 145-230.

Rüdorff (1873), Poggen. Annalen, cxlviii. pp. 456 and 555 .

Others who have touched upon it are :-

Regavault, Joum. de Pharm. et de Chimie, xliii. p. 187, xliv. p. 187.

Pratr, Ann. der Ch. u. Pharm. xcix. p. 224.

LoNgChamp, Otto-Graham, ii. 2, p. 188.

Schauefrele, Journ. de Pliarm. [3] xvii. p. 268.

Tobler (double sulphates), Ann. Ch.u. Pharm. xcv. p. 198.

Before considering the results obtained by former observers, I shall describe my own experiments and state their results.

Four salts were taken for examination-the chlorides of sodium and potassium, and the corresponding nitrates; and their solubility and density at $20^{\circ} \mathrm{C}$. were carefully determined in the following way. A large bath, fitted up as

* It is curious that the temperatures $32^{\circ}-33^{\circ}$ and $64^{\circ}-66^{\circ}$ should be marked out so definitely as those at which decomposition of hydrated salts takes place. Thus, $32^{\circ}-33^{\circ}$, as above, is the $t^{\circ}$ at which sodium carbonate and sulphate decompose; $\mathrm{CaCl}_{2} 6 \mathrm{H}_{2} \mathrm{O}$ melts at $33^{\circ}$. The solubility of $\mathrm{Sr}\left(\mathrm{NO}_{3}\right)_{2}$ increases much less rapidly after $32^{\circ}$ is reached, while the same is the case at $66^{\circ}$ with $\mathrm{SrCl}_{2}$. The solubilitiy of $\mathrm{MnSO}_{4}$, which drops suddenly at $54^{\circ}$, remains constant from $64^{\circ}$ for more than $20^{\circ} ; \mathrm{FeSO}_{4}$, maximum at $63^{\circ} \cdot 5$. The melting-point determinations of Wiedemann give critical points at $32^{\circ}$, at $63^{\circ}$, and $92^{\circ}$ (Wied. Annul. xrii. p. 561). 
described in a previous paper*, was provided with a cover pierced with holes to hold test-tubes 180 millim. by 30 millim. Round the top of the bath ran a tube with stopcocks at intervals, corresponding to the holes in the cover; this tube was connected with the air-blower. The course of experiment was as follows:-Two test-tubes with 50 cubic centim. of water in each were taken, and an excess of the same salt placed in each. The contents of one of the tubes were heated till solution was complete, and after partial cooling both tubes were placed in the bath at, say, 12 noon. By means of wide tubes attached to the stopcocks at the side of the bath, a slow stream of air saturated with water vapour was allowed to bubble up through the solutions in the test-tubes, which were loosely covered. The whole was left till 10 A.M. the next day, when the air-current was turned off, and the solutions were left at rest till 12 o'clock. In this way saturation had gone on in one of the tubes, and crystallization in the other for 24 hours. By means of a cork titted with two tubes, one wide and sufficiently long to reach nearly to the bottom of the testtube, and covered at the lower end with two-ply of cambric, a portion of the liquid was forced by air-pressure into a Sprengel tube placed in the bath, and another portion collected in a weighed dish. In this way the specific gravity and percentage composition of the solution saturated at $20^{\circ} \mathrm{C}$. were found.

The results were as follows:-

TABLE IV.

\begin{tabular}{|c|c|c|c|c|c|}
\hline$t^{\circ}$. & Salt. & $\delta$. & M. V. & $n$. & $\frac{r}{n}$ \\
\hline 20 & & & & & \\
\hline$n$ & $\mathrm{NaCl}$ & $1 \cdot 20191$ & $2032 \cdot 76$ & $10 \cdot 99$ & $21 \cdot 2$ \\
$"$ & $\mathrm{NaNO}_{3}$ & $1 \cdot 17777$ & $2058 \cdot 79$ & $8 \cdot 377$ & $30 \cdot 9$ \\
& $1 \cdot 38608$ & $2430 \cdot 15$ & $18 \cdot 45$ & $34 \cdot 2$ \\
$\mathrm{KNO}_{3}$ & $1 \cdot 16500$ & 2032.96 & $5 \cdot 63$ & $41 \cdot 4$ \\
\hline
\end{tabular}

The last column $\frac{r}{n}$ is the mean molecular volume of each molecule of the salt in a saturated solution.

Similar experiments were made with the following pairs of salts :-

(1) $\mathrm{NaCl}+\mathrm{KCl}$;

(3) $\mathrm{KCl}+\mathrm{KNO}_{3}$;

(2) $\mathrm{NaNO}_{3}+\mathrm{NaCl}$;

(4) $\mathrm{KNO}_{3}+\mathrm{NaNO}_{3}$.

The results are given in full to show the amount of accuracy attained.

* Phil. Mag. 1883, p. 389.

$$
202
$$



$\mathrm{NaCl}+\mathrm{KCl}$.
(1) $31 \cdot 39$ per cent. $\} 45 \cdot 6 / 100^{*}$. Mol. wt. $=2623 \cdot 3$.
(1) $\delta=1 \cdot 236897$
(2) $\delta=1 \cdot 23697\}$ Mol. vol. $=2120 \cdot 8$.

The potassium and sodium estimated as sulphates gave :Ratio $\mathrm{KCl}: \mathrm{NaCl}\left\{\begin{array}{l}(1) \mathrm{R}=1 \cdot: 1 \cdot 706, \\ (2) \mathrm{R}=1 \cdot: 1 \cdot 613 .\end{array}\right.$

Mean ratio $=1: 1 \cdot 66$.

And a number of compound molecules $(\mathrm{KCl} 1.66 \mathrm{NaCl})=$ $4 \cdot 795$.

$$
\mathrm{NaNO}+\mathrm{NaCl} \text {. }
$$

(1) $43 \cdot 67$ per cent. $\} 76 \cdot 93 / 100$. Mol. wt. $=3184 \cdot 7$.

(1) $\delta=1 \cdot 36133\}$

(2) $\delta=1 \cdot 36172\}$ Mol. vol. $=2339 \cdot 1$.

Chlorine determined as $\mathrm{AgCl}:-$

NaCl. $: \mathrm{NaNO}_{3} . \quad$ Ratio $=\left\{\begin{array}{l}(1) 1: 1 \cdot 465, \\ (2) 1: 1 \cdot 422 .\end{array}\right.$

Mean ratio $=1: 1 \cdot 444$.

Number of compound molecules $=7 \cdot 64$.

(1) $34 \cdot 45$ per cent. $\} 52 \cdot 67 / 100$. Mol. wt. $=2748 \cdot 1$.

(1) $\left.\begin{array}{l}\delta=1 \cdot 2484 " \\ (2)=1 \cdot 24878\end{array}\right\}$ Mol. vol. $=2200 \cdot 9$.

Chlorine as $\mathrm{AgCl}:-$

$\mathrm{KNO}_{3}: \mathrm{KCl}$. Ratio $=1: 2 \cdot 36$.

Number of compound molecules $=3 \cdot 42$.

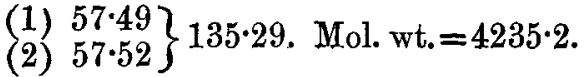

(1) $\left.\begin{array}{l}\delta=1 \cdot 49608 \\ \text { (2) } \delta=1 \cdot 49624\end{array}\right\}$ Mol. vol. $=2830 \cdot 6$.

Sodium and potassium as sulphates :-

$\mathrm{KNO}_{3}: \mathrm{NaNO}_{3} . \quad$ Ratio $=\left\{\begin{array}{l}(1) 1: 2 \cdot 46, \\ (2) 1: 2 \cdot 44 .\end{array}\right.$

Mean ratio $=1: 2 \cdot 45$.

Number of compound molecules $=7 \cdot 87$.

In Table $V$. the leading results of the above experiments are given with those of calculations based on them. In column B are given the number of salt-molecules of each salt * $x / 100=$ parts of salt per 100 of water. 
TABLE V.

\begin{tabular}{|c|c|c|c|c|c|c|c|c|}
\hline Salts. & R. & $\begin{array}{l}\text { Compound } \\
\text { molecules. }\end{array}$ & A. & B. & $A \times B$ & $\begin{array}{l}(A \times B) \\
+1800 .\end{array}$ & $\begin{array}{l}\text { Mol. } \\
\text { vol. }\end{array}$ & Diff. \\
\hline $\begin{array}{l}\mathrm{KCl} \\
\mathrm{NaCl}\end{array} \ldots . .$. & $\begin{array}{l}1 \\
1 \cdot 66\end{array}$ & $4 \cdot 795$ & $\begin{array}{l}30 \cdot 9 \\
21 \cdot 2\end{array}$ & $\begin{array}{l}4.795 \\
7 \cdot 96\end{array}$ & $\begin{array}{l}148 \cdot 2 \\
168 \cdot 8\end{array}$ & $2117 \cdot 0$ & $2120 \cdot 8$ & +38 \\
\hline $\begin{array}{l}\mathrm{NaCl} \ldots . . \\
\mathrm{NaNO}_{3} . .\end{array}$ & $\begin{array}{l}1 \\
1 \cdot 444\end{array}$ & $7 \cdot 64$ & $\begin{array}{l}21 \cdot 2 \\
34 \cdot 2\end{array}$ & $\begin{array}{l}7 \cdot 64 \\
11 \cdot 03\end{array}$ & $\begin{array}{l}161 \cdot 2 \\
377 \cdot 2\end{array}$ & 2338.5 & $2339 \cdot 1$ & $+\cdot 6$ \\
\hline $\begin{array}{l}\mathrm{KNO}_{3} \\
\mathrm{KCl}\end{array}$ & $\begin{array}{l}1 \\
2 \cdot 36\end{array}$ & $3 \cdot 42$ & $\begin{array}{l}41 \cdot 4 \\
30 \cdot 9\end{array}$ & $\begin{array}{l}3 \cdot 42 \\
8 \cdot 07\end{array}$ & $\begin{array}{l}141 \cdot 6 \\
249 \cdot 4\end{array}$ & $2191 \cdot 0$ & $2200 \cdot 9$ & +9.9 \\
\hline $\begin{array}{ll}\mathrm{KNO}_{3} & . . \\
\mathrm{NaNO}_{3} & . .\end{array}$ & $\begin{array}{l}1 \\
2 \cdot 45\end{array}$ & $7 \cdot 87$ & $\begin{array}{l}41 \cdot 4 \\
34 \cdot 2\end{array}$ & $\begin{array}{l}7 \cdot 87 \\
19 \cdot 29\end{array}$ & $\begin{array}{l}325 \cdot 8 \\
659 \cdot 7\end{array}$ & $2785 \cdot 5$ & $2830 \cdot 6$ & $+45 \cdot 1$ \\
\hline
\end{tabular}

$A=$ mean mol. vol. in saturated solution of the salt alone.

$\mathrm{B}=$ number of salt-molecules present in the saturated solution of both salts. present in a saturated solution per $100 \mathrm{H}_{2} \mathrm{O}$. Comparing these numbers with those in Table IV., we find that in Case (1) the solubibity has increased for :-

$$
\begin{array}{lcrr}
\mathrm{NaCl} & \text { from } 10.99 \text { to } & 15.92 \\
\mathrm{KCl} & \# & 8.38, & \mathbf{9} 59
\end{array}
$$

Case (2),

$\mathrm{NaCl}, \quad 10.99,15 \cdot 28$

$\mathrm{NaNO}_{3} \quad \# \quad 18 \cdot 45,22 \cdot 06$

Case (3),

$\begin{array}{llll}\mathrm{KNO}_{3} & , \quad 5.68, & 6.84\end{array}$

$\mathrm{KCl} \quad$ " $8.38,16.14$

Case (4),

$\mathrm{KNO}_{3} \quad, \quad 5 \cdot 68,15 \cdot 74$

$\mathrm{NaNO}_{3} \quad, \quad 18.45,38.58$

This is on the assumption that each salt takes one half of the water present in the solution. The solubility has therefore increased in every case.

Again the ratio together and separate is :-

\begin{tabular}{|c|c|c|c|c|}
\hline $\mathrm{NaCl}$ & & 1 & & 1 \\
\hline$\overline{\mathrm{NaNO}_{3}}$ & $"$ & $\overline{1.444}$ & $"$ & $\overline{1.679^{\circ}}$ \\
\hline$\frac{\mathrm{KNO}_{3}}{\mathrm{KCl}}$ & $"$ & $\frac{1}{2 * 36}$ & $"$ & $\frac{1}{1 \cdot 488}$. \\
\hline$\frac{\mathrm{KNO}_{3}}{\mathrm{NaNO}_{3}}$, & $"$ & $\frac{1}{2 \cdot 45}$ & $"$ & $3 \cdot 27 ?$ \\
\hline
\end{tabular}

$\frac{\mathrm{KCl}}{\mathrm{NaCl}}$, together $\frac{1}{1 \cdot 66}$, separate $\frac{1}{1 \cdot 31}$. 
Here the more soluble salt has its solubility increased more than that of the less soluble, with the exception of $\mathrm{NaNO}_{3}$, since $\mathbf{R}$ together $<\mathrm{R}$ separate.

The more important part of Table $V$. is in the last four columns, where I have compared the actual molecular volume of the salt-solution with the volume calculated on the supposition that each salt-molecule is present in the solution with the volume it possesses in its own saturated solution. In the three first cases the agreement is satisfactory; but $\mathrm{KNO}_{3}+\mathrm{NaNO}_{3}$ is exceptional, the actual volume of the salts being about 10 per cent. higher than the calculated. I may venture to suggest that a possible explanation of this is to be found in the fact that $\mathrm{KNO}_{3}$ is dimorphous, and in one of its forms (that of rhombohedra) is isomorphous with $\mathrm{NaNO}_{3}$. It may be that the presence of this last salt may influence the form in which the $\mathrm{KNO}_{3}$ would crystallize out; and inasmuch as the isomorphous form is the unstable one under usual conditions, it is probable that its molecular volume in the solid state would be greater, and hence its solubility and molecular volume in a saturated solution would also be greater than that of the usual form.

I have examined this point in another way: by preparing a solution of one of the above salts, and then adding to it, after determination of the molecular volume, a number of molecules of another salt: for example, a $7 \mathrm{NaCl} 100 \mathrm{H}_{2} \mathrm{O}$ solution had $2 \mathrm{KCl}, 3 \mathrm{KCl}$, and $4 \mathrm{KCl}$ added.

The results are given in Table VI., and compared with the molecular volume calculated on the supposition that the more

TABLe VI.

\begin{tabular}{|c|c|c|c|c|c|}
\hline & $\mathbf{M}^{\prime} . \mathbf{V}^{\prime}$. & $n$ & M. V. & $\begin{array}{r}\mathbf{M}^{\prime} \cdot \nabla^{\prime} \cdot \times n \\
+1800\end{array}$ & Diff. \\
\hline $\begin{array}{l}\mathrm{NaCl} \\
\mathrm{NaCl} \\
\mathrm{KaCl}^{\mathrm{KOC}}\end{array}$ & $\begin{array}{l}20.7 \\
30.9\end{array}$ & $\begin{array}{l}7 \\
7 \\
2\end{array}$ & $\left\{\begin{array}{l}1941 \cdot 5 \\
2007 \cdot 5\end{array}\right.$ & 20067 & +8 \\
\hline $\begin{array}{ll}\mathrm{NaCl} & \ldots \\
\mathrm{KCl} & \ldots\end{array}$ & $\begin{array}{l}209 \\
30 \cdot 9\end{array}$ & $\begin{array}{l}7 \\
3\end{array}$ & $2040 \cdot 5$ & $2039 \cdot 0$ & +1.5 \\
\hline $\begin{array}{ll}\mathrm{NaCl} & \ldots \\
\mathrm{KOl} & \ldots\end{array}$ & $\begin{array}{l}21 \cdot 2 \\
30 \cdot 9\end{array}$ & $\begin{array}{l}7 \\
4\end{array}$ & $2074 \cdot 1$ & $2072 \cdot 0$ & +21 \\
\hline $\begin{array}{ll}\mathrm{KOl} & \ldots \\
\mathrm{KOl} & \ldots \\
\mathrm{KNO}_{3} & \ldots\end{array}$ & $\begin{array}{l}3090 \\
41 \cdot 4\end{array}$ & $\begin{array}{l}7 \\
7 \\
2\end{array}$ & $\begin{array}{r}2010.9 \\
2098.6\end{array}$ & $2099 \cdot 1$ & -5 \\
\hline
\end{tabular}


soluble salt possesses a molecular volume the same as it would if all the salt-molecules present were the same, and that the less soluble salt possesses the molecular rolume it has in a saturated solution. There is here very complete agreement between the two sets of figures.

Enough has been said to show that in the majority of the cases examined the molecular volume of the saturated solution is equal to the sum of the molecular volumes of the salts present, calculated on the hypothesis that each salt has the volume it would possess in its own saturated solution.

The results of previous experimenters on this subject are given in Table VII. I shall at present content myself with pointing out the general conclusions to be derived from it, reserving for future discussion the special points of difficulty. I do so with the less hesitation, since the data here given are liable to the same charges of inaccuracy that are made with so much truth against ordinary solubility determinations.

Out of forty-two determinations (including duplicates) there are thirty instances in which the more soluble salt has its solubility increased by the presence of another salt to a greater extent than that of the less soluble one.

In no instance is the solubility of the more soluble salt less than if it were alone in the solution, while in several instances it is doubled. In twelve cases the less soluble salt suffers a diminution of solubility; in all the others the reverse is the case.

The general rule appears to be that the solubility of two salts together is greater than that when separate. "The probable explanation of this appears to me to be as follows:-

Each salt dissolves independently of the other. This is shown by the molecular volume of the solution. Each salt, however, increases in most cases the solubility of the other by what may be called mechanical means: thus, molecules of different salts do not, as a rule, attract one another; there is therefore no tendency to form a system containing two salts. At the same time, however, the formation of groups of similar salt-molecules is prevented to a certain extent by the interposition or collision with a molecule of the other salt: thus the number of similar salt-molecules must be increased bofore, in unit time, the number of encounters of similar molecules becomes as great as in a saturated solution of that salt alone.

The increased solubility of the more soluble salt at the expense, so to speak, of the less soluble salt is in all probability due to the greater attraction for water possessed by that particular salt. This is specially noticeable in the case of $\mathrm{CaCl}_{2}$. 
In conclusion, I am fully aware that it is only by numerous and careful experiments that it is possible to decide whether the above results are merely fortuitous, or are part of a wider generalization; and I hope, at no distant date, to be able to bring forward further evidence in this direction.

\section{TABLE VII.}

Same Metal.

\begin{tabular}{|c|c|c|c|c|c|c|c|c|}
\hline Salts. & $t^{\circ}$ & $\begin{array}{l}\text { Solu- } \\
\text { bility } \\
\text { separ. }\end{array}$ & $\begin{array}{c}\text { Solu- } \\
\text { bility } \\
\text { together. }\end{array}$ & $\begin{array}{l}\text { Mol. } \\
\text { separ. }\end{array}$ & $\begin{array}{l}\text { Mol. } \\
\text { tog. }\end{array}$ & $\begin{array}{c}\text { R. } \\
\text { separ. }\end{array}$ & $\begin{array}{c}\text { R. } \\
\text { tog. }\end{array}$ & Authority. \\
\hline $\begin{array}{l}\mathrm{KOl} \\
\mathrm{KNO}\end{array}$ & $\begin{array}{c}12 \cdot 9 \\
" y\end{array}$ & $\begin{array}{l}32 \cdot 8 \\
23 \cdot 9\end{array}$ & $\begin{array}{l}28 \cdot 5 \\
18 \cdot 8\end{array}$ & $\begin{array}{l}4 \cdot 4 \\
2 \cdot 36\end{array}$ & $\begin{array}{l}3 \cdot 82 \\
1 \cdot 86\end{array}$ & 1.86 & 2.06 & Kopp. \\
\hline $\begin{array}{l}\mathrm{KCl} \\
\mathrm{KNO}_{3} \ldots\end{array}$ & $\begin{array}{r}15 \\
,\end{array}$ & $\begin{array}{l}33 \cdot 5 \\
26 \cdot 3\end{array}$ & $\begin{array}{l}28 \cdot 8 \\
18 \cdot 9\end{array}$ & $\begin{array}{l}4 \cdot 49 \\
2 \cdot 6\end{array}$ & $\begin{array}{l}3 \cdot 86 \\
18 \cdot 7\end{array}$ & $1 \cdot 73$ & 2.07 & Kopp. \\
\hline $\begin{array}{l}\mathrm{KCl} \\
\mathrm{KNO} \mathrm{O}_{3} \ldots \ldots \ldots\end{array}$ & $\begin{array}{r}20 \\
, \prime\end{array}$ & $\begin{array}{l}34 \cdot 7 \\
31 \cdot 2\end{array}$ & $\begin{array}{l}35 \cdot 2 \\
19 \cdot 1\end{array}$ & $\begin{array}{l}4 \cdot 65 \\
3 \cdot 09\end{array}$ & $\begin{array}{l}4.72 \\
1.89\end{array}$ & 1.51 & $2 \cdot 5$ & Rüdorff. \\
\hline$\frac{\mathrm{KI}}{\mathrm{K}_{2} \mathrm{SO}_{4}} \frac{\ldots \ldots \ldots \ldots}{2} \ldots \ldots \ldots$ & $\begin{array}{c}14: 5 \\
" ~\end{array}$ & $\begin{array}{r}139 \cdot 8 \\
10 \cdot 2\end{array}$ & $\begin{array}{r}137 \cdot 6 \\
1 \cdot 0\end{array}$ & $\begin{array}{l}8 \cdot 42 \\
1 \cdot 17\end{array}$ & $\begin{array}{r}8 \cdot 28 \\
\cdot 12\end{array}$ & $7 \cdot 19$ & $72 \cdot 0$ & Mulder. \\
\hline $\mathrm{KI} \ldots \ldots \ldots \ldots$ & $\begin{array}{c}21.5 \\
\prime \prime\end{array}$ & $\begin{array}{r}146 \cdot 2 \\
35 \cdot 2\end{array}$ & $\begin{array}{r}133 \cdot 2 \\
10 \cdot 4\end{array}$ & $\begin{array}{l}8 \cdot 8 \\
4 \cdot 7\end{array}$ & $\begin{array}{l}8 \cdot 02 \\
1 \cdot 39\end{array}$ & 1.87 & $5 \cdot 74$ & $R$. \\
\hline $\begin{array}{l}\mathrm{KNO}_{3} \ldots \\
\frac{\mathrm{K}_{2} \mathrm{SO}_{4}}{2} \ldots\end{array}$ & $\begin{array}{c}18 \cdot 7 \\
"\end{array}$ & $\begin{array}{l}29 \cdot 9 \\
10 \cdot 8\end{array}$ & $\begin{array}{r}29 \cdot 42 \\
4 \cdot 00\end{array}$ & $\begin{array}{l}2 \cdot 96 \\
1 \cdot 24\end{array}$ & $\begin{array}{r}2 \cdot 91 \\
\cdot 46\end{array}$ & $2 \cdot 38$ & 6.33 & Karsten. \\
\hline $\begin{array}{l}\mathrm{KNO}_{3} \ldots . \\
\frac{\mathrm{K}_{2} \mathrm{SO}_{4}}{2} \ldots . .\end{array}$ & $\begin{array}{c}20 \\
;\end{array}$ & $\begin{array}{l}31 \cdot 2 \\
10 \cdot 9\end{array}$ & $\begin{array}{r}26 \cdot 9 \\
6 \cdot 6\end{array}$ & $\begin{array}{l}3.08 \\
1.25\end{array}$ & $\begin{array}{r}2 \cdot 66 \\
\cdot 76\end{array}$ & $2 \cdot 47$ & $3 \cdot 51$ & Kopp. \\
\hline $\begin{array}{l}\mathrm{KNO}_{3} \ldots \ldots \\
\frac{\mathrm{K}_{2} \mathrm{SO}_{4}}{2} \ldots \ldots\end{array}$ & 40 & $\begin{array}{l}64 \cdot 0 \\
14 \cdot 0\end{array}$ & $\begin{array}{r}59 \cdot 3 \\
5 \cdot 8\end{array}$ & $\begin{array}{l}6.33 \\
1.6\end{array}$ & $\begin{array}{r}5 \cdot 87 \\
\cdot 67\end{array}$ & $3 \cdot 94$ & $8 \cdot 81$ & Kopp. \\
\hline $\begin{array}{l}\mathrm{NaNO}_{3} \\
\mathrm{NaCl}\end{array}$ & $\begin{array}{c}18 \cdot 7 \\
"\end{array}$ & $\begin{array}{l}86 \cdot 6 \\
36 \cdot 0\end{array}$ & $\begin{array}{l}52 \cdot 85 \\
2504\end{array}$ & $\begin{array}{r}10 \cdot 19 \\
6 \cdot 15\end{array}$ & $\begin{array}{l}6 \cdot 22 \\
4 \cdot 28\end{array}$ & 1.66 & $1 \cdot 45$ & \\
\hline $\begin{array}{ll}\mathrm{NaNO}_{3} & \ldots \ldots \\
\mathrm{NaCl} & \ldots \ldots \ldots\end{array}$ & 20 & $\begin{array}{l}87 \cdot 5 \\
36 \cdot 0\end{array}$ & $\begin{array}{l}56 \cdot 8 \\
24 \cdot 6\end{array}$ & $\begin{array}{c}10 \cdot 3 \\
6 \cdot 15\end{array}$ & $\begin{array}{l}6 \cdot 68 \\
4 \cdot 51\end{array}$ & $1 \cdot 67$ & $1 \cdot 48$ & R. \\
\hline $\begin{array}{l}\mathrm{NH}_{4} \mathrm{NO}_{3} \quad \ldots \\
\mathrm{NH}_{4} \mathrm{Cl}\end{array}$ & $\begin{array}{c}19 \cdot 5 \\
" y\end{array}$ & $\begin{array}{r}183 \cdot 0 \\
37 \cdot 0\end{array}$ & $\begin{array}{r}173 \cdot 8 \\
29 \cdot 1\end{array}$ & $\begin{array}{r}22 \cdot 9 \\
6.9\end{array}$ & $\begin{array}{c}21 \cdot 7 \\
5 \cdot 44\end{array}$ & 3.31 & 3.99 & R. \\
\hline $\begin{array}{l}\frac{\left(\mathrm{NH}_{4}\right)_{2} \mathrm{SO}_{4}}{2} \ldots \\
\mathrm{NH}_{4} \mathrm{Cl} \ldots \ldots\end{array}$ & $\begin{array}{c}21 \cdot 5 \\
,\end{array}$ & $\begin{array}{l}75 \cdot 6 \\
37 \cdot 8\end{array}$ & $\begin{array}{l}46 \cdot 5 \\
26 \cdot 8\end{array}$ & $\begin{array}{c}11.5 \\
7 \cdot 07\end{array}$ & $\begin{array}{l}7 \cdot 05 \\
5 \cdot 01\end{array}$ & $1 \cdot 62$ & $1 \cdot 4$ & $\mathbf{R}$. \\
\hline
\end{tabular}


Saturation of Salt-Solutions.

Same Salt-Radical.

\begin{tabular}{|c|c|c|c|c|c|c|c|c|}
\hline Salts. & $t^{\circ}$ & $\begin{array}{l}\text { Solu- } \\
\text { bility } \\
\text { separ. }\end{array}$ & $\begin{array}{c}\text { Solu- } \\
\text { bility } \\
\text { together. }\end{array}$ & $\begin{array}{c}\text { Mol. } \\
\text { separ. }\end{array}$ & $\begin{array}{c}\text { Mol. } \\
\text { tog. }\end{array}$ & $\begin{array}{c}\text { R. } \\
\text { separ. }\end{array}$ & $\underset{\text { tog. }}{R .}$ & Authority. \\
\hline $\mathrm{KCl}$. & $16 \cdot 6$ & $33 \cdot 8$ & $27 \cdot 2$ & $4 \cdot 53$ & $7 \cdot 3$ & & & \\
\hline$\frac{\mathrm{BaCl}_{2}}{2}$. & $"$ & $34 \cdot 9$ & $18 \cdot 2$ & $3 \cdot 36$ & $3 \cdot 5$ & $1 \cdot 35$ & $2 \cdot 1$ & Kopp. \\
\hline $\mathrm{NaOl}$ & 10 & $35 \cdot 8$ & $30 \cdot 0$ & $6 \cdot 12$ & $5 \cdot 13$ & .983 & $1 \cdot 4$ & M. \\
\hline $\mathrm{NH}_{4} \mathrm{Cl} \quad \ldots \ldots$ & $"$ & $33 \cdot 3$ & $19 \cdot 5$ & & & & & \\
\hline $\begin{array}{l}\mathrm{NaCl} \ldots \ldots . . . \\
\mathrm{NH}_{4} \mathrm{Cl} \quad \ldots \ldots . .\end{array}$ & $\begin{array}{c}18 \cdot 7 \\
"\end{array}$ & $\begin{array}{l}36 \cdot 0 \\
36 \cdot 7\end{array}$ & $\begin{array}{l}26 \cdot 38 \\
22 \cdot 06\end{array}$ & $\begin{array}{l}6 \cdot 15 \\
6 \cdot 86\end{array}$ & $\begin{array}{l}4 \cdot 51 \\
4 \cdot 12\end{array}$ & .897 & 1.09 & \\
\hline $\mathrm{NaCl}$ & boiling & $40 \cdot 4$ & $22 \cdot 3$ & 6.91 & 3.81 & 0.36 & 3.85 & \\
\hline $\mathrm{NH}_{4} \mathrm{Cl}$ & $"$ & $87 \cdot 3$ & $78 \cdot 5$ & 1632 & $14 \cdot 57$ & 230 & 380 & NII. \\
\hline $\mathrm{NaCl}$ & 17 & 35.9 & $4 \cdot 1$ & $6 \cdot 14$ & $\cdot 7$ & & & \\
\hline$\frac{\mathrm{BaCl}_{2}}{2}$ & $"$ & 35.0 & $34 \cdot 5$ & 3.37 & $3 \cdot 32$ & $?$ & $?$ & Kopp. \\
\hline $\mathrm{NaCl}$ & boiling & $40 \cdot 4$ & $35 \cdot 3$ & $6 \cdot 91$ & $6 \cdot 03$ & & & \\
\hline$\frac{\mathrm{BaCl}_{2}}{2}$ & ", & $60 \cdot 3$ & $19 \cdot 4$ & 5.8 & 1.87 & $1 \cdot 19$ & $3 \cdot 24$ & M. \\
\hline $\begin{array}{l}\mathrm{NaCl} \\
\mathrm{KCl} . .\end{array}$ & $\begin{array}{c}18 \cdot 8 \\
"\end{array}$ & $\begin{array}{l}36 \cdot 0 \\
34 \cdot 3\end{array}$ & $\begin{array}{l}29 \cdot 9 \\
15 \cdot 7\end{array}$ & $\begin{array}{l}6 \cdot 15 \\
4 \cdot 6\end{array}$ & $\begin{array}{l}5 \cdot 11 \\
2 \cdot 11\end{array}$ & $1 \cdot 34$ & $2 \cdot 43$ & $\mathrm{R}$. \\
\hline $\mathrm{NH}_{4} \mathrm{C}$ & $20 \cdot 5$ & $37 \cdot 4$ & $22 \cdot 9$ & $6 \cdot 99$ & $4 \cdot 28$ & $1 \cdot 13$ & 1.05 & R. \\
\hline & $"$ & 36.0 & & & & & & \\
\hline $\begin{array}{l}\mathrm{NH}_{4} \mathrm{Cl} \\
\mathrm{KCl}^{2} .\end{array}$ & $\begin{array}{r}15 \\
"\end{array}$ & $\begin{array}{l}35 \cdot 2 \\
33 \cdot 4\end{array}$ & $\begin{array}{l}28 \cdot 9 \\
17 \cdot 1\end{array}$ & $\begin{array}{l}6 \cdot 58 \\
4 \cdot 48\end{array}$ & $\begin{array}{l}5 \cdot 4 \\
2 \cdot 29\end{array}$ & 1.47 & $2 \cdot 36$ & R. \\
\hline $\begin{array}{l}\mathrm{NH}_{4} \mathrm{Cl} \\
\mathrm{KCl}\end{array}$ & $\begin{array}{c}18 \cdot 7 \\
\Rightarrow\end{array}$ & $\begin{array}{l}36 \cdot 7 \\
34 \cdot 4\end{array}$ & $\begin{array}{l}29 \cdot 83 \\
16 \cdot 27\end{array}$ & $\begin{array}{l}6 \cdot 86 \\
4 \cdot 61\end{array}$ & $\begin{array}{l}5 \cdot 57 \\
2 \cdot 19\end{array}$ & $1 \cdot 49$ & $2 \cdot 55$ & Kopp. \\
\hline $\begin{array}{l}\mathrm{NH}_{4} \mathrm{CI} \\
\mathrm{KCl}\end{array}$ & 22 & 38.0 & $\begin{array}{l}30 \cdot 4 \\
19 \cdot 1\end{array}$ & $\begin{array}{l}7 \cdot 1 \\
4 \cdot 73\end{array}$ & $\begin{array}{l}5 \cdot 68 \\
2 \cdot 56\end{array}$ & $1 \cdot 5$ & $2 \cdot 22$ & $\mathrm{R}$. \\
\hline $\begin{array}{l}\mathrm{NH}_{4} \mathrm{Cl} \\
\mathrm{KCl} . .\end{array}$ & boiling & $\begin{array}{l}87 \cdot 3 \\
58 \cdot 5\end{array}$ & $\begin{array}{l}67 \cdot 7 \\
21 \cdot 9\end{array}$ & $\begin{array}{r}16.32 \\
7.84\end{array}$ & $\begin{array}{r}12.65 \\
2.94\end{array}$ & $2 \cdot 08$ & $4: 31$ & M. \\
\hline $\mathrm{NH} \mathrm{CI}$ & 20 & $37 \cdot 2$ & 33.8 & 6.95 & 6.32 & & & \\
\hline $\mathrm{BaCl}_{2}$ & & 0,2 & 11.6 & $3 \cdot 43$ & 1.11 & 2.02 & $5 \cdot 66$ & M. \\
\hline$\overline{2}$ & & $30 \%$ & & 0.0 & 121 & & & \\
\hline$\underline{\mathrm{CaCl}_{2}}$. & 7 & $56 \cdot 0$ & 63.5 & 10.09 & $11 \cdot 44$ & 9.43 & $17 \cdot 4$ & $\mathbf{M}$ \\
\hline$\stackrel{2}{\mathrm{KCl}}$ & ", & $31 \cdot 0$ & $4 \cdot 9$ & $4 \cdot 16$ & 66 & & & IIS. \\
\hline$\underline{\mathrm{CaCl}_{2}}$ & 7 & 560 & 39.5 & $10 \cdot 09$ & $7 \cdot 12$ & 1.65 & 9005 & M. \\
\hline$\stackrel{2}{\mathrm{NaCl}}$ & " & $35 \cdot 7$ & $4 \cdot 6$ & $6 \cdot 1$ & .79 & & & \\
\hline$\frac{\mathrm{CaCl}_{2}}{3}$ & 4 & $53 \cdot 0$ & $57 \cdot 6$ & $9 \cdot 55$ & $10 \cdot 38$ & $1 \cdot 56$ & $25 \cdot 3$ & PM. \\
\hline$\stackrel{2}{\mathrm{NaCl}}$ & $"$ & 357 & $2 \cdot 4$ & $6 \cdot 1$ & $\cdot 41$ & & & \\
\hline
\end{tabular}




\begin{tabular}{|c|c|c|c|c|c|c|c|c|}
\hline Salts. & $t^{\circ}$. & $\begin{array}{l}\text { Solu- } \\
\text { bility } \\
\text { separ. }\end{array}$ & $\begin{array}{c}\text { Solu- } \\
\text { bility } \\
\text { togetber. }\end{array}$ & $\begin{array}{l}\text { Mol. } \\
\text { separ. }\end{array}$ & $\begin{array}{l}\text { Mol. } \\
\text { tog. }\end{array}$ & $\begin{array}{c}\mathrm{R} . \\
\text { separ. }\end{array}$ & $\begin{array}{l}\mathbf{R .} \\
\text { tog. }\end{array}$ & Authority. \\
\hline \multirow{8}{*}{ 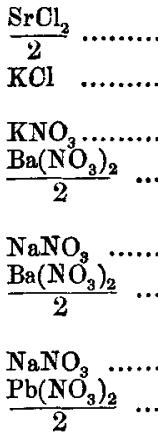 } & \multirow[t]{2}{*}{$14 \cdot 5$} & 507 & $48 \cdot 6$ & 6.39 & $6 \cdot 13$ & \multirow{2}{*}{$1 \cdot 44$} & \multirow{2}{*}{408} & \multirow{2}{*}{ M. } \\
\hline & & $33 \cdot 2$ & $11 \cdot 2$ & $4 \cdot 45$ & 1.5 & & & \\
\hline & \multirow[t]{2}{*}{$18 \cdot 5$} & $29 \cdot 7$ & $28 \cdot 8$ & $2 \cdot 94$ & $2 \cdot 85$ & \multirow[b]{2}{*}{$4 \cdot 3$} & \multirow[b]{2}{*}{$6 \cdot 88$} & \multirow[b]{2}{*}{$\mathbf{M}$. } \\
\hline & & 8.9 & 5.4 & 68 & $\cdot 41$ & & & \\
\hline & $18 \cdot 7$ & $86 \cdot 6$ & $88 \cdot 14$ & $10 \cdot 19$ & $10 \cdot 27$ & & & \\
\hline & $"$ & $8 \cdot 9$ & $3 \cdot 77$ & $\cdot 68$ & $\cdot 29$ & $15 \cdot 3$ & $35 \cdot 9$ & Karsten. \\
\hline & $15 \cdot 6$ & $84 \cdot 4$ & $84 \cdot 3$ & $9 \cdot 93$ & $9 \cdot 92$ & & & \\
\hline & $"$ & $48 \cdot 7$ & $33 \cdot 6$ & $2 \cdot 94$ & $2 \cdot 03$ & $3 \cdot 37$ & 4.88 & Корр. \\
\hline $\mathrm{NaNO}_{3}, \ldots .$. & $18 \cdot 7$ & $86 \cdot 6$ & $87 \cdot 75$ & $10 \cdot 19$ & $10 \cdot 33$ & & & \\
\hline$\frac{\mathrm{Pb}\left(\mathrm{NO}_{3}\right)_{2}}{2} \ldots$ & $"$ & $51 \cdot 3$ & $34 \cdot 26$ & $3 \cdot 1$ & $2 \cdot 07$ & $3 \cdot 29$ & $4 \cdot 48$ & Rarsten. \\
\hline $\mathrm{NaNO}_{3}, \ldots .$. & 20 & $87 \cdot 5$ & $84 \cdot 6$ & $10 \cdot 3$ & 9.96 & & & Konn \\
\hline$\frac{\mathrm{Pb}\left(\mathrm{NO}_{3}\right)_{2}}{2} \cdots$ & $"$ & $52 \cdot 3$ & $38 \cdot 4$ & $3 \cdot 16$ & $2 \cdot 32$ & 326 & 429 & Aopp. \\
\hline $\mathrm{NaNO}_{3}, \ldots \ldots$ & $14 \cdot 5$ & $83 \cdot 7$ & $66 \cdot 4$ & $9 \cdot 85$ & $7 \cdot 81$ & & & \\
\hline$\frac{\mathrm{Sr}\left(\mathrm{NO}_{3}\right)_{2}}{2} \ldots \ldots$ & " & $62 \cdot 0$ & $51 \cdot 0$ & $5 \cdot 86$ & 4.82 & 168 & $1 \cdot 62$ & M. \\
\hline $\begin{array}{l}\mathrm{NH}_{4} \mathrm{NO}_{3} \ldots \\
\mathrm{KNO}_{3} \ldots \ldots \ldots\end{array}$ & 11 & $\begin{array}{r}143 \cdot 0 \\
20 \cdot 2\end{array}$ & $\begin{array}{l}88 \cdot 8 \\
40 \cdot 6\end{array}$ & $\begin{array}{r}17 \cdot 9 \\
2 \cdot 0\end{array}$ & $\begin{array}{r}11 \cdot 1 \\
4 \cdot 0\end{array}$ & $8 \cdot 95$ & $3 \cdot 75$ & M. \\
\hline $\begin{array}{ll}\mathrm{NH}_{4} \mathrm{NO}_{3} & \ldots \\
\mathrm{KNO}_{3} & \ldots \ldots \ldots\end{array}$ & $\begin{array}{r}15 \\
"\end{array}$ & $\begin{array}{r}161 \cdot 0 \\
26 \cdot 0\end{array}$ & $\begin{array}{r}130 \cdot 4 \\
46 \cdot 2\end{array}$ & $\begin{array}{r}20 \cdot 13 \\
2 \cdot 57\end{array}$ & $\begin{array}{c}16 \cdot 3 \\
4 \cdot 57\end{array}$ & $7 \cdot 82$ & $3 \cdot 57$ & M. \\
\hline $\begin{array}{ll}\mathrm{NH}_{2} \mathrm{NO}_{3} & \ldots . \\
\mathrm{NaNO}_{3} & \ldots . . .\end{array}$ & $\begin{array}{r}16 \\
,\end{array}$ & $\begin{array}{r}166 \cdot 0 \\
84 \cdot 7\end{array}$ & $\begin{array}{r}162 \cdot 9 \\
77 \cdot 1\end{array}$ & $\begin{array}{r}20 \cdot 75 \\
9 \cdot 96\end{array}$ & $\begin{array}{r}20 \cdot 36 \\
9 \cdot 07\end{array}$ & $2 \cdot 08$ & $2 \cdot 24$ & $\mathrm{R}$. \\
\hline $\mathrm{NH}_{4} \mathrm{NO}_{3} \quad \ldots$ & 10 & $143 \cdot 0$ & $119 \cdot 9$ & $17 \cdot 9$ & 13.95 & 6.70 & 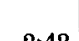 & \\
\hline$\frac{\mathrm{Pb}\left(\mathrm{NO}_{3}\right)_{2}}{2} \ldots$ & " & $43 \cdot 6$ & $67 \cdot 5$ & $2 \cdot 63$ & 4.08 & 8 & 540. & M. \\
\hline $\mathrm{NH}_{4} \mathrm{NO}_{3} \ldots \ldots$ & 10 & $143 \cdot 0$ & $101 \cdot 3$ & $17 \cdot 9$ & $12 \cdot 67$ & $34 \cdot 3$ & $26 \cdot 6$ & \\
\hline$\frac{\mathrm{Ba}\left(\mathrm{NO}_{3}\right)_{2}}{2} \ldots$ & " & 688 & $6 \cdot 2$ & $\cdot 52$ & $\cdot 48$ & & & $M$ \\
\hline$\frac{\mathrm{Pb}\left(\mathrm{NO}_{3}\right)_{2}}{2}$ & $21 \cdot 2$ & $53 \cdot 3$ & $119 \cdot 6$ & $3 \cdot 22$ & $7 \cdot 23$ & $1 \cdot 0$ & $1 \cdot 09$ & $\mathbf{R}$ \\
\hline $\mathrm{KNO}_{3} \ldots \ldots . .$. & " & $32 \cdot 6$ & $67 \cdot 1$ & $3 \cdot 23$ & $6 \cdot 32$ & & & \\
\hline$\frac{\left(\mathrm{NH}_{4}\right)_{2} \mathrm{SO}_{4}}{2} \ldots$ & 10 & $73 \cdot 0$ & $50 \cdot 6$ & $11 \cdot 06$ & $7 \cdot 67$ & & & $M$ \\
\hline$\frac{\mathrm{K}_{2} \mathrm{SO}_{4}}{2} \cdot$. & $"$ & $9 \cdot 8$ & $7 \cdot 2$ & $1 \cdot 13$ & $\cdot 83$ & 900 & 820 & III. \\
\hline
\end{tabular}

The solubility is expressed in parts per 100 of water, and is taken from Mulder (loc. cit.). The solubility in molecules is referred to 1000 parts of water, and is calculated from the abore. 